\title{
KARAKTERISTIK FISIKA KIMIA PERAIRAN DAN STRUKTUR KOMUNITAS ZOOPLANKTON DI ESTUARI SUNGAI BANYUASIN, SUMATERA SELATAN
}

\author{
Eko Prianto'), Husnah ${ }^{2)}$, dan Solekha Aprianti ${ }^{2)}$ \\ 1) Peneliti pada Pusat Penelitian Pengelolaan Perikanan dan Konservasi Sumber Daya Ikan, Ancol-Jakarta \\ 2) Peneliti pada Balai Riset Perikanan Perairan Umum, Mariana-Palembang \\ Teregistrasi I tanggal: 11 Agustus 2010; Diterima setelah perbaikan tanggal: 19 Nopember 2010; \\ Disetujui terbit tanggal: 30 Nopember 2010
}

\begin{abstract}
ABSTRAK
Penelitian ini bertujuan untuk mengetahui kondisi kualitas perairan pasca pembangunan Pelabuhan Tanjung Api-Api dengan mempelajari karakteristik fisika kimia perairan dan struktur komunitas zooplankton. Penelitian tentang kelimpahan dan keanekaragaman jenis zooplankton dilakukan melalui enam titik stasiun pengamatan di muara Sungai Banyuasin pada bulan April sampai Nopember 2009. Contoh air diambil pada kedalaman $1 \mathrm{~m}$ dari permukaan air dengan menggunakan kemmerer water sampler dan contoh zooplankton diambil dengan menggunakan ember $50 \mathrm{~L}$ pada permukaan perairan. Selanjutnya contoh air disaring dengan menggunakan plankton net dengan ukuran $25 \mu \mathrm{m}$. Hasil analisis kualitas air diperoleh nilai parameter (suhu, $\mathrm{pH}, \mathrm{NO}_{2}, \mathrm{COD}$, $\mathrm{BOD}$, dan DO) berada dalam ambang batas yang diperbolehkan sesuai dengan Peraturan Pemerintah No.82 Tahun 2001. Nilai parameter padatan tersuspensi (total suspended solids), total dissolved solid, amoniak, nitrat, dan fosfat telah melebihi ambang batas lingkungan perairan yang diperbolehkan. Nilai indeks mutu lingkungan perairan menunjukan dalam kondisi tercemar berat. Kelimpahan zooplankton pada tahun 2009 yaitu 2-19 ind/L lebih rendah dari kelimpahan pada tahun 2004 yaitu 534 ind/L sedangkan keanekaragaman jenis pada tahun 2009 mengalami penurunan jika dibandingkan tahun 2004.
\end{abstract}

KATAKUNCl: $\quad$ estuari, fisika kimia, zooplankton, Sungai Banyuasin

ABSTRACT: The physico chemical characteristics of waters and community structure of zooplankton in estuary Banyuasin after development of Tanjung Api-Api Port. By: Eko Prianto, Husnah, and Solekha Aprianti

\begin{abstract}
The aims of this study were to determine water quality conditions after construction of the port of Tanjung Api-Api by studying the physico chemical characteristics of water and zooplankton community structure. Research on zooplankton abundance and species diversity through the six points of observation stations in the estuary of the river Banyuasin in April until November 2009. Water samples taken at a depth of $1 \mathrm{~m}$ from water surface water by using a kemmerer water sampler and zooplankton samples were taken by using a bucket about $50 \mathrm{~L}$ in the surface. Further water samples were filtered using a plankton net with a size $25 \mu \mathrm{m}$. The results of water quality analize obtained that parameter values (temperature, $\mathrm{pH}, \mathrm{NO}_{2}, \mathrm{COD}, \mathrm{BOD}$, and $\mathrm{DO}$ ) were still in the threshold limit, in accordance with Government Regulation No.82 2001. Value parameters of total suspended solids, total dissolved solid, ammonia, nitrate, and phosphate has exceeded the permissible limit aquatic environment. Value of water environmental quality index showed in heavily polluted conditions. Zooplankton abundance in was 2-19 ind/L lower than the abundance in 2004 of 5-34 ind/L, while species diversity in the year 2009 decreased compared to 2004.
\end{abstract}

KEYWORDS: $\quad$ estuary, physical chemistry, zooplankton, Banyuasn River

\section{PENDAHULUAN}

Zooplankton merupakan jasad renik atau organisme air yang memiliki peranan yang besar dalam rantai makanan, yaitu sebagai konsumer pertama yang memakan fitoplankton, selanjutnya zooplankton ini dimakan oleh organisme lain yang lebih tinggi tingkatannya seperti udang dan ikan (Soedarsono et al., 2002). Berbeda dengan fitoplankton, zooplankton memiliki alat gerak yang sangat kecil sehingga pergerakannya lambat dan terbatas. Pergerakan zooplankton dalam perairan lebih banyak dipengaruhi oleh arus. Jenis dan kelimpahan zooplankton dapat berubah-ubah sesuai dengan kondisi lingkungan perairan. Jenis yang dapat beradaptasi baik dengan lingkungannya akan mendominansi wilayah tersebut.

Sungai Banyuasin di Sumatera Selatan saat ini telah menjadi pusat kegiatan masyarakat di sekitarnya, di antaranya kegiatan perikanan (penangkapan dan tambak udang), transportasi, perkebunan, pemukiman, dan industri. Meningkatnya intensitas kegiatan ini telah memberikan dampak yang 
cukup besar terhadap keseimbangan ekosistem Sungai Banyuasin. Permasalahan lain yang mengancam kelestarian sumber daya perairan adalah aktivitas di wilayah hulu sungai seperti pertanian, perkebunan, industri, dan pemukiman yang secara terus-menerus memberikan dampak yang cukup besar terhadap ekosistem sungai. Bahan pencemar yang dihasilkan setiap kegiatan akan dibawa arus sungai menuju wilayah hilir, di wilayah ini bahan tersebut akan terakumulasi sehingga wilayah hilir mengandung cemaran yang cukup tinggi.

Masalah lain yang sedang dihadapi Sungai Banyuasin adalah pengembangan Pelabuhan Tanjung Api-Api seluas 40.000 ha. Pembangunan pelabuhan ini disertai dengan membangun infrastruktur jalan, pemukiman, dan jembatan yang mengharuskan konversi hutan mangrove. Dampak yang dihasilkan pembangunan proyek ini diperkirakan akan dirasakan dalam waktu yang cukup panjang yang dapat memberikan pengaruh buruk terhadap kualitas perairan Sungai Banyuasin.

Kualitas perairan sangat berpengaruh terhadap kelangsungan hidup organisme perairan. Keberadaan zooplankton di suatu perairan dapat dipengaruhi oleh faktor-faktor fisika kimia perairan. Untuk tumbuh dan berkembang dengan baik zooplankton memiliki batas toleransi parameter fisika kimia perairan. Paterson (1998) mengatakan bahwa komunitas zooplankton sangat sensitif terhadap perubahan lingkungan. Perubahan pada struktur komunitas zooplankton (keragaman, kelimpahan, dominansi, dan keseragaman) mengindikasikan bahwa perairan tersebut telah mendapat gangguan atau terjadi perubahan-perubahan. Penelitian ini bertujuan untuk mengetahui karakteristik fisika kimia perairan dan struktur komunitas zooplankton di perairan Sungai Banyuasin pasca pembangunan Pelabuhan Tanjung Api-Api.

\section{BAHAN DAN METODE}

\section{Waktu dan Lokasi Penelitian}

Penelitian ini dilakukan di perairan estuari Sungai Banyuasin di daerah Tanjung Api-Api, Provinsi Sumatera Selatan pada bulan April sampai Nopember 2009. Pengumpulan data primer dilakukan melalui metode observasi (survey lapangan) pada enam stasiun pengambilan contoh yang mewakili perairan estuari Sungai Banyuasin. Penentuan stasiun pengambilan contoh dilakukan dengan pendekatan tujuan tertentu (purposive sampling) (Gambar 1).

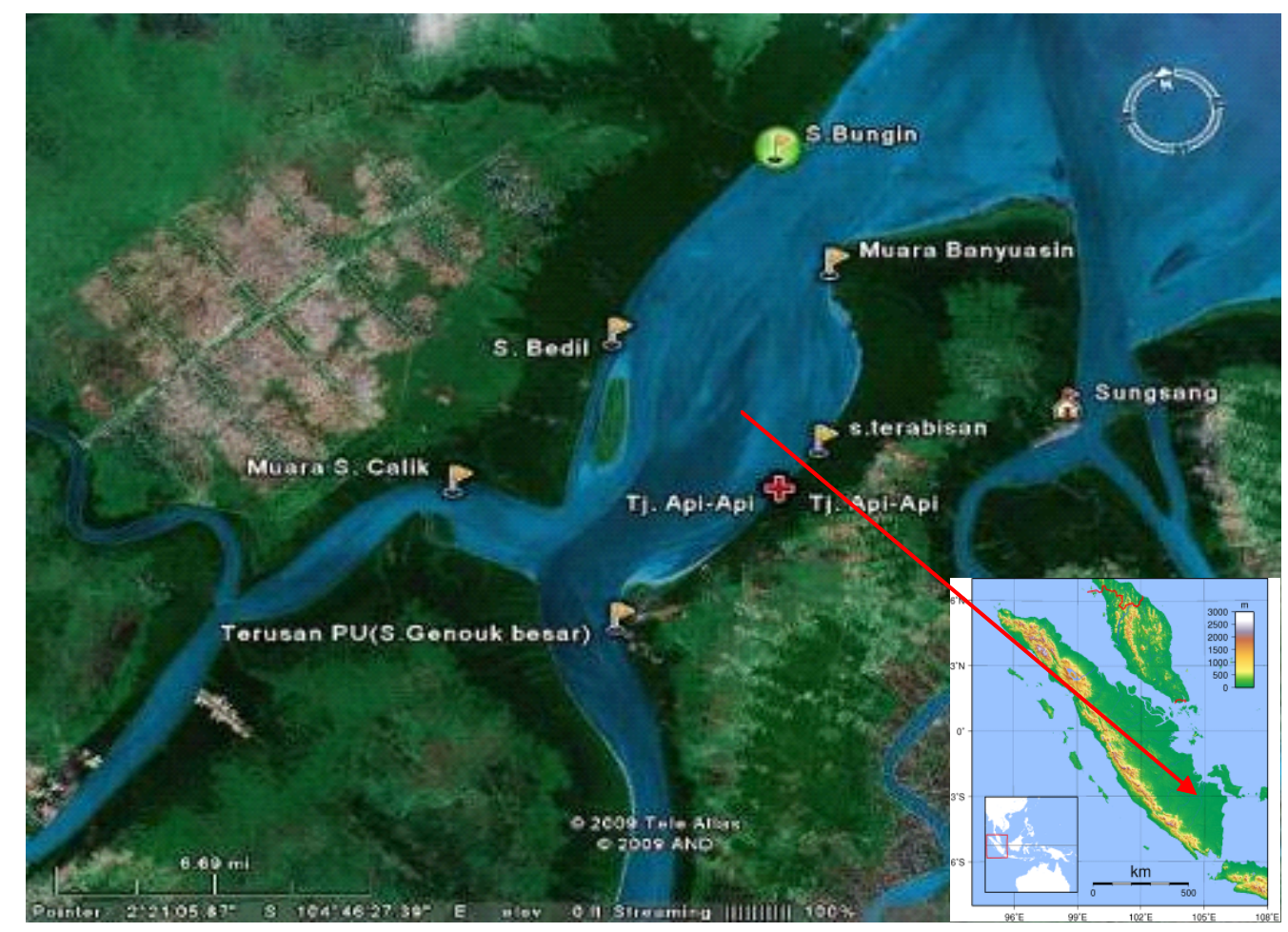

Gambar 1. Lokasi pengambilan contoh air di muara Sungai Banyuasin, bulan April sampai Nopember 2009.

Figure 1. Sampling station of water sample in the estuary of Banyuasin river, April until November 2009. 


\section{Pengambilan Contoh}

Contoh air diambil dengan menggunakan kemmerer water sampler. Parameter suhu, salinitas, kecepatan arus, kedalaman, kecerahan, warna, bau, $\mathrm{pH}$, dan oksigen terlarut dianalisis di lapangan. Parameter total suspended solid, total disolved solid, alkalinitas, hardness, BOD, dan daya hantar listrik, bahan organik, total nitrat, dan total fosfat dianalisis di laboratorium Balai Riset Perikanan Perairan Umum, Palembang.

Contoh air diambil pada kedalaman $1 \mathrm{~m}$ dari permukaan dan kemudian dimasukan ke dalam botol contoh $500 \mathrm{ml}$, diawetkan pada suhu kurang dari $4^{\circ} \mathrm{C}$ dan segera dianalisis. Pengambilan contoh $\mathrm{BOD}_{5}$ dilakukan di bagian tengah sungai, contoh selanjutnya dimasukan ke dalam botol gelap $300 \mathrm{ml}$ dan disimpan pada suhu $20^{\circ} \mathrm{C}$.

Pengambilan contoh zooplankton menggunakan ember $50 \mathrm{~L}$ menjadi $25 \mathrm{ml}$ pada permukaan perairan dengan menggunakan plankton net ukuran $25 \mu \mathrm{m}$ dan diawetkan menggunakan formalin $4 \%$. Identifikasi zooplankton menggunakan acuan Mizuno (1979); Downing \& Rigler (1984). Pengamatan zooplankton menggunakan mikroskop dengan pembesaran 20 kali.

\section{Analisis Data}

\section{Contoh air}

Untuk menentukan kualitas perairan, maka beberapa parameter fisika kimia yang dihasilkan dibandingkan dengan baku mutu lingkungan yang berlaku di Indonesia (Peraturan Pemerintah No.82 Tahun 2001) tentang pengelolaan kualitas air dan pengendalian pencemaran air. $\mathrm{Hal}$ ini dibandingkan dengan kriteria baku mutu air berdasarkan atas kelas III (untuk keperluan perikanan). Untuk mengetahui perubahan kualitas perairan akibat pembangunan Tanjung Api-Api selanjutnya dibandingkan dengan nilai kualitas perairan pada tahun 2004 berdasarkan atas kajian Analisis Mengenai Dampak Lingkungan Pelabuhan Tanjung Api-Api (Badan Pengendalian Dampak Lingkungan Daerah Pemerintah Provinsi Sumatera Selatan, 2004).

\section{Zooplankton}

\section{a. Kelimpahan}

Pengamatan kelimpahan zooplankton dilakukan menurut American Public Health Association (1980) dengan rumus sebagai berikut:
$\mathrm{N}=\underline{\mathrm{Nsxva}}$

vsXvc

di mana:

$\mathrm{N}=$ kelimpahan zooplankton (ind $/ \mathrm{L}$ )

Ns = jumlah zooplankton pada sedgewick-rafter counting cell

$\mathrm{Va}=$ volume air yang terkonsentrasi dalam contoh $(\mathrm{mL})$

Vs = volume air dalam preparat sedgwick rafter counting cell $(\mathrm{mL})$

Vc $=$ volume air contoh yang disaring $(\mathrm{mL})$

\section{b. Keanekaragaman jenis}

$H=\sum_{i=1}^{S} p i \log _{2} p i$

di mana:

$$
\begin{aligned}
& \mathrm{H}=\text { indeks keanekaragaman jenis } \\
& \mathrm{S}=\text { banyaknya jenis (taxa) } \\
& \mathrm{Pi}=\text { proporsi individu dari jenis ke-i terhadap } \\
& \quad \text { jumlah individu semua jenis } \\
& \mathrm{ni}=\text { banyaknya individu atau jenis (taxa) } \\
& \mathrm{N}=\text { total individu semua jenis }
\end{aligned}
$$

\section{Indeks Mutu Lingkungan Perairan}

Penilaian kondisi lingkungan perairan menggunakan indeks mutu lingkungan perairan yang telah dikembangkan oleh US-National Sanitation Foundation Water Quality Index menurut Ott (1978), dengan rumus:

$\mathrm{n}$

$$
\operatorname{IMLP}=\underset{\mathrm{i}=1}{\sum(\mathrm{Wix}} \text { li) }
$$

di mana:

$\mathrm{Wi}=$ bobot parameter ke-i, skala 0-1

$\mathrm{i}=$ nilai sub indeks (parameter DO, pH, BOD5, $\mathrm{N}-\mathrm{NO} 3$, fosfat, suhu, kekeruhan, dan padatan tersuspensi

li = nilai dari kurva baku indeks ke-i, skala 0100

Hasil perhitungan indeks mutu lingkungan perairan kemudian dibandingkan dengan kriteria baku mutu lingkungan perairan menurut US-National Sanitation Foundation Water Quality Index (Ott, 1978) seperti pada Tabel 1. 
Tabel 1. Kriteria mutu lingkungan perairan (US-National Sanitation Foundation Water Quality Index) Table 1. Criteria of water quality (US-National Sanitation Foundation Water Quality Index)

\begin{tabular}{ccc}
\hline No. & $\begin{array}{c}\text { Indeks mutu lingkungan perairan/ } \\
\text { Water environment quality index }\end{array}$ & $\begin{array}{c}\text { Keterangan/ } \\
\text { Remarks }\end{array}$ \\
\hline 1. & $0-25$ & Sangat buruk \\
2. & $26-50$ & Buruk \\
3. & $51-70$ & Sedang \\
4. & $71-90$ & Baik \\
5. & $91-100$ & Sangat baik \\
\hline
\end{tabular}

Sumber/Sources: Ott (1978)

\section{HASIL DAN BAHASAN}

\section{Kualitas Perairan}

Hasil analisis data kualitas air, pada tahun 2004 mengalami perubahan pada beberapa parameter sedangkan sebagian parameter lain belum mengalami perubahan. Perubahan-perubahan ini diguga akibat meningkatnya aktivitas manusia seperti industri, pelabuhan, alih fungsi lahan untuk pembangunan Tanjung Api-Api. Nilai parameter fisika kimia perairan yang diukur disajikan dalam pada Tabel 2 .

Tabel 2. Parameter fisika kimia perairan di estuaria Sungai Banyuasin tahun 2004 dan 2009

Table 2. Physico chemical parameter in the estuary of Banyuasin rivers in 2004 and 2009

\begin{tabular}{|c|c|c|c|c|c|c|c|}
\hline \multirow{3}{*}{ No. } & \multirow{3}{*}{$\begin{array}{c}\text { Parameter } \\
\text { kualitas air/ } \\
\text { Water quality } \\
\text { parameter }\end{array}$} & \multirow{3}{*}{$\begin{array}{c}\text { Satuan/ } \\
\text { Unit }\end{array}$} & \multicolumn{4}{|c|}{ Tahun/Year } & \multirow{3}{*}{$\begin{array}{c}\text { Peraturan } \\
\text { Pemerintah } \\
\text { No.82 } \\
\text { Tahun } 2001 \\
\end{array}$} \\
\hline & & & \multicolumn{3}{|c|}{2009} & 2004 & \\
\hline & & & April & Juni & Agustus & April-Juni & \\
\hline 1. & Kecepatan Arus & $\mathrm{cm} / \mathrm{dtk}$ & $45-119$ & $25-67$ & $12-52$ & - & - \\
\hline 2. & Kecerahan & $\mathrm{cm}$ & $9,5-20$ & $12-32$ & $12-57$ & - & - \\
\hline 3. & Warna & - & $\begin{array}{c}\text { Coklat } \\
\text { kekuningan }\end{array}$ & $\begin{array}{c}\text { Coklat } \\
\text { kekuningan }\end{array}$ & $\begin{array}{c}\text { Coklat } \\
\text { kekuningan }\end{array}$ & - & - \\
\hline 4. & Bau & - & Tidak berbau & Tidak berbau & Tidak berbau & - & - \\
\hline 5. & Suhu & ${ }^{\circ} \mathrm{C}$ & $29-31,8$ & 29-31 & - & $29,3-29,7$ & Deviasi 3 \\
\hline 6. & $\mathrm{pH}$ & unit & 6,5-7 & $7-7,5$ & $7-7,5$ & 7,4 & 6-9 \\
\hline 7. & TDS & $\mathrm{mg} / \mathrm{L}$ & $>1.990$ & $>1990$ & $>1990$ & $225-360$ & 1.000 \\
\hline 8. & TSS & $\mathrm{mg} / \mathrm{L}$ & $71-339$ & 57-198 & $73-690$ & $180-196,7$ & 50 \\
\hline 9. & Amoniak $\left(\mathrm{H}-\mathrm{NH}_{3}\right)$ & $\mathrm{mg} / \mathrm{L}$ & $1,75-4,25$ & $0,025-0,27$ & $0,31-0,48$ & $0,27-0,31$ & 0 \\
\hline 10. & Nitrit $\left(\mathrm{H}-\mathrm{NO}_{2}\right)$ & $\mathrm{mg} / \mathrm{L}$ & $0,026-0,062$ & $0,01-0,021$ & $0,003-0,014$ & $0,02-0,04$ & $<0,06$ \\
\hline 11. & COD & $\mathrm{mg} / \mathrm{L}$ & $3,49-9,98$ & $3,41-6,16$ & $0,33-4$ & $4-5,4$ & 50 \\
\hline 13. & Fosfat $\left(\mathrm{P}-\mathrm{PO}_{4}\right)$ & $\mathrm{mg} / \mathrm{L}$ & $0,2-1,8$ & $4,7-10,7$ & 1,7-7,6 & - & $<1$ \\
\hline 14. & Nitrat $\left(\mathrm{H}-\mathrm{NO}_{3}\right)$ & $\mathrm{mg} / \mathrm{L}$ & $8,3-12,6$ & $11,04-18,6$ & $27,3-41,9$ & - & $<2$ \\
\hline 15. & DO & $\mathrm{mg} / \mathrm{L}$ & $3,39-5,01$ & $2,6-4,2$ & $3,8-5,8$ & - & $>3$ \\
\hline
\end{tabular}

Keterangan/Remarks: (-) data tidak tersedia/(-) no data available

Dari Tabel 2 dapat dilihat nilai parameter (suhu, $\mathrm{pH}$, nitrit $\left(\mathrm{N}-\mathrm{NO}_{2}\right), \mathrm{COD}, \mathrm{BOD}$, dan $\mathrm{DO}$ ) pada tahun 2004 dan 2009 berada dalam ambang batas yang diperbolehkan sesuai dengan Peraturan Pemerintah No.82 Tahun 2001. Dibandingkan tahun 2004, nilai BOD meningkat sampai mencapai nilai tertinggi 5,33 $\mathrm{mg} / \mathrm{L}$ terutama pada bulan Oktober, sedangkan nilai parameter lain berada dalam kisaran yang sama. Kecepatan arus berkisar antara $12-119 \mathrm{~cm} / \mathrm{dtk}$ dan kecerahan perairan cukup rendah berkisar antara 9,5$57 \mathrm{~cm}$. Rendahnya kecerahan disebabkan pengaruh pasang surut perairan yang dapat mengakibatkan pengadukan dasar perairan (turbulen).
Nilai padatan tersuspensi (total suspended solids), total dissolved solid, amoniak, nitrat, dan fosfat telah berada di atas ambang batas yang diperbolehkan. Perubahan nilai parameter kualitas perairan ini dapat disebabkan karena perubahan lingkungan akibat aktivitas manusia (pelabuhan, perkebunan, dan industri).

Kecerahan dan total dissolved solid merupakan parameter yang saling berkaitan. Peningkatan konsentrasi total dissolved solid dalam perairan akan meningkatkan kekeruhan air dan sebaliknya akan mengurangi kecerahannya. Hasil pengukuran kecerahan dilokasi studi diperoleh nilai kecerahan 
berkisar 9,5-32 $\mathrm{cm}$. Nilai kecerahan ini tergolong rendah karena kecerahan di estuari dipengaruhi turbulensi arus pasang surut dan juga peningkatan aktivitas pembukaan lahan di sekitar Sungai Banyuasin.

Hasil pengukuran total suspended solids (tahun 2009) berkisar antara 57-690 dan $197 \mathrm{mg} / \mathrm{L}$ (tahun 2004). Nilai tersebut telah melampaui nilai baku mutu lingkungan perairan. Lokasi yang memiliki nilai tinggi terdapat di stasiun Terabisan (690 mg/L) dan Sungai Calik $420 \mathrm{mg} / \mathrm{L}$ terutama terjadi di bulan Oktober. Secara umum, nilai total suspended solids pada tahun 2009 lebih tinggi dari pada tahun 2004.

Nitrogen merupakan salah satu unsur penting bagi pertumbuhan organisme dan pembentukan protein. Di perairan, nitrogen terdapat dalam bentuk gas $\mathrm{N}_{2}$, nitrit $\left(\mathrm{N}-\mathrm{NO}_{2}\right)$, nitrat $\left(\mathrm{N}-\mathrm{NO}_{3}\right)$, dan amoniak $\left(\mathrm{N}^{-} \mathrm{NH}_{3}\right)$ (Alaerts \& Santika, 1984). Hasil pengukuran nilai amoniak pada masing-masing stasiun berkisar antara 1,75-4,25 mg/L (bulan April); antara 0,025-0,27 mg/L (bulan Juni) dan antara 0,31-0,48 mg/L (bulan Oktober). Pada tahun 2004 berkisar antara 0,27-0,31 $\mathrm{mg} / \mathrm{L}$. Secara keseluruhan, nilai ini melampaui ambang batas maksimum baku mutu lingkungan yang berlaku di Indonesia untuk kepentingan perikanan di mana kandungan amoniak bebas untuk ikan $\leq 0,02 \mathrm{mg} / \mathrm{L}$. Tingginya konsentrasi amoniak di Sungai Banyuasin diduga berasal dari limpasan pupuk yang berada di sekitar perkebunan dan terbawa dari kegiatan di daerah hulu.

Unsur fosfat di perairan tidak ditemukan dalam bentuk bebas sebagai elemen, melainkan dalam bentuk senyawa anorganik yang terlarut (orthofosfat dan polifosfat) dan senyawa organik yang berupa partikulat (Effendie, 2003). Hasil pengamatan pada masing-masing stasiun diperoleh nilai $\mathrm{P}-\mathrm{PO}_{4}$ pada bulan Juni dan Oktober telah melebihi baku mutu lingkungan perairan untuk keperluan perikanan $(<1$ $\mathrm{mg} / \mathrm{L}$ ), sedangkan pada bulan April hanya di Sungai Bungin dan Muara Banyuasin yang melampaui batas baku mutu lingkungan perairan. Tingginya nilai fosfat di dalam perairan diduga karena pengaruh dari perkebunan yang berada di sekitar lokasi studi yang menggunakan pupuk untuk meningkatkan kesuburan tanah. Keberadaan fosfat secara berlebihan yang disertai dengan keberadaan nitrogen dapat menstimulir pertumbuhan ganggang (Effendie, 2003).

Nitrat adalah bentuk senyawa nitrogen yang merupakan sebuah senyawa stabil. Nitrat merupakan salah satu senyawa penting untuk sintesis protein tumbuhan dan hewan, akan tetapi nitrat pada konsentrasi tinggi dapat menstimulasi pertumbuhan ganggang yang tidak terbatas (Alaerts \& Santika, 1984). Hasil pengukuran nitrat di lokasi studi berkisar antara 8,33-13,76 mg/L (bulan April); antara 11,04$18,65 \mathrm{mg} / \mathrm{L}$ (bulan Juni) dan antara 27,27-41,98 mg/L (bulan Oktober). Nilai ini telah melampaui baku mutu lingkungan perairan untuk perikanan (<2). Tingginya nilai nitrat di dalam perairan diduga karena pengaruh dari perkebunan yang berada di sekitar lokasi studi yang menggunakan pupuk untuk meningkatkan kesuburan tanah

\section{Struktur Komunitas Zooplankton}

\section{a. Komposisi jenis dan kelimpahan}

Tingginya kekeruhan dan fluktuasi salinitas di perairan muara menyebabkan hanya jenis tertentu yang dapat hidup. Jumlah jenis zooplankton yang ditemukan di perairan Sungai Banyuasin pada bulan Maret 11 jenis, bulan Juni 14 jenis, dan bulan Oktober 10 jenis. Sedangkan jumlah jenis keseluruhan zooplankton di Sungai Banyuasin 20 jenis. Pada tahun 2004 jumlah jenis zooplankton yang ditemukan di Sungai Banyuasin 13 jenis yang terdiri atas lima kelas (Flagella, Ciliata, Rhizopoda, Copepoda, dan Gastropoda (Tabel 3). Prianto et al. (2008) mengatakan jumlah jenis zooplankton di muara Sungai Musi pada masing-masing musim berbeda. Jumlah jenis yang tertinggi (35 jenis) dijumpai pada musim peralihan dan terendah ( 13 jenis) pada musim kemarau. Jumlah jenis yang ditemukan di Muara Musi lebih banyak dibandingkan dengan Sungai Banyuasin, di mana pada musim peralihan (bulan Juni) 35 jenis sedangkan di musim yang sama di Sungai Banyuasin hanya 11 jenis.

Pada tahun 2009 kelimpahan zooplankton di Sungai Banyuasin berkisar antara 2.000-19.000 ind/ $\mathrm{m}^{3}$ (Gambar 2). Pada tahun 2004 berkisar 5.000$34.000 \mathrm{ind} / \mathrm{m}^{3}$. Rendahnya kelimpahan zooplankton pada tahun 2009 diduga karena pengaruh lingkungan perairan di sekitar Sungai Banyuasin seperti alih fungsi hutan mangrove untuk pembangunan pelabuhan dan perkebunan. Hasil penelitian Prianto et al. (2008) menemukan kelimpahan zooplankton di muara Sungai Musi berkisar antara 2.100-7.200 ind. $/ \mathrm{m}^{3}$ (bulan Januari), antara 5.500-8.100 ind. $/ \mathrm{m}^{3}$ (bulan Mei), dan $1.300-3.800$ ind. $/ \mathrm{m}^{3}$ (bulan September).

Kelimpahan zooplankton di perairan dipengaruhi oleh faktor fisika, kimia, dan biologi perairan di antaranya faktor fisika (suhu, kecerahan, kedalaman, dan arus), sedangkan faktor kimia (oksigen terlarut, 
Tabel 3. Jenis-jenis zooplankton yang ditemukan di estuaria Sungai Banyuasin tahun 2009 dan 2004 Table 3. Zooplankton species found in the estuary of Banyuasin rivers in 2009 and 2004

\begin{tabular}{|c|c|c|c|c|}
\hline No. & Jenis Zooplankton & Kelas/Class & 2009 & 2004 \\
\hline 1. & Diaptomus sp. & Crustacea & * & * \\
\hline 2. & Difflugia sp. & Mastigophora & * & * \\
\hline 3. & Peridinium sp. & Mastigophora & * & \\
\hline 4. & Trachelomonas sp. & Mastigophora & * & * \\
\hline 5. & Colpoda sp. & Ciliata & * & \\
\hline 6. & Tintinnopsis sp. & Ciliata & * & \\
\hline 7. & Tintinnidium sp. & Ciliata & * & \\
\hline 8. & Keratella sp. & Rotatoria & * & \\
\hline 9. & Protozoa sp. & Protozoa & * & \\
\hline 10. & Trichocercha sp. & Rotatoria & * & \\
\hline 11. & Nauplius sp. & Crustacea & * & \\
\hline 12. & Oxytrica sp. & Ciliata & * & \\
\hline 13. & Stentor sp. & Ciliata & * & \\
\hline 14. & Cyclops sp. & Crustacea & * & \\
\hline 15. & Notholcha sp. & Rotatoria & * & \\
\hline 16. & Argonotholca sp. & Rotatoria & * & \\
\hline 17. & Anureopsis sp. & Monogonotha & * & \\
\hline 18. & Monostyla sp. & Monogonotha & * & \\
\hline 19. & Lepocinclis ovum & Flagella & & * \\
\hline 20. & Heonema ciliate & Ciliata & & * \\
\hline 21. & Plagiocampa mutabilis & Ciliata & & * \\
\hline 22. & Spirozoma caudate & Ciliata & & * \\
\hline 23. & Vorticella campanula & Ciliata & & * \\
\hline 24. & Thecamoeba sp. & Rhizopoda & & * \\
\hline 25. & Diaptomus marshianus & Copepoda & & * \\
\hline 26. & Melocorona (larva) & Gastropoda & & * \\
\hline
\end{tabular}

Keterangan/Remarks: ${ }^{*}$ ada

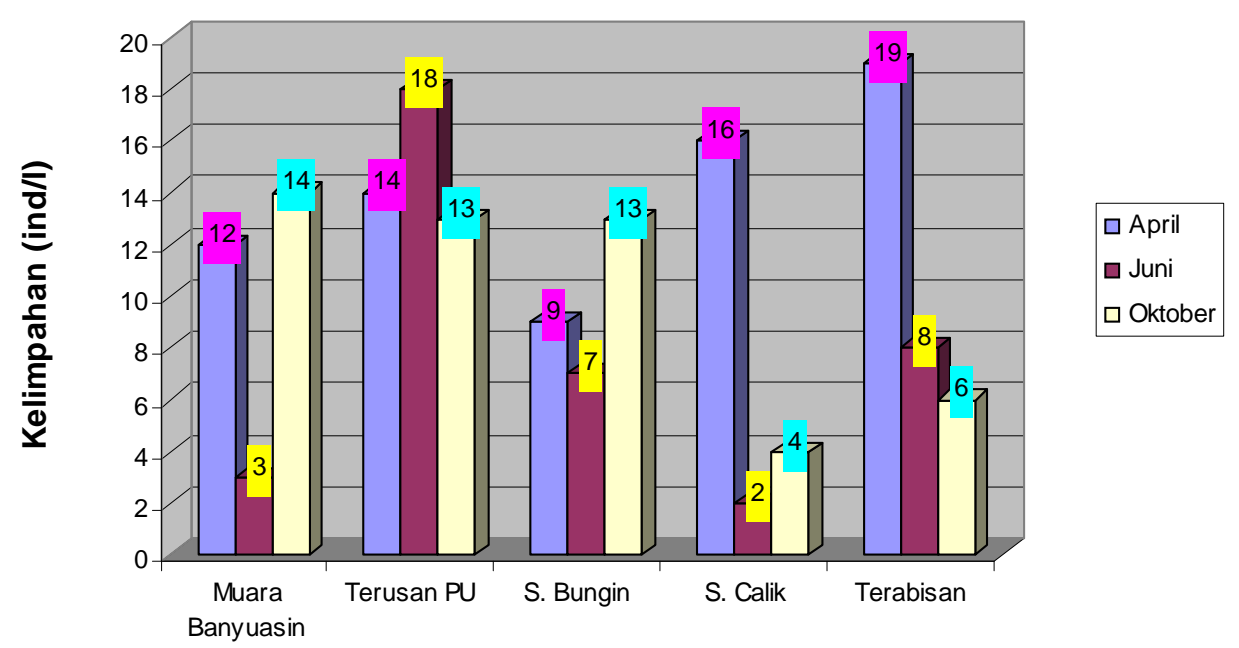

\section{Stasiun Penelitian}

Gambar 2. Kelimpahan zooplankton menurut stasiun penelitian, tahun 2009.

Figure 2. $\quad$ Abundance of zooplankton by sampling stasion, 2009.

karbondioksida, $\mathrm{pH}$, salinitas, dan nutrien), (Raymond, 1963).

Penyebaran zooplankton di sungai sangat dipengaruhi oleh arus. Di Sungai Musi bagian hilir kecepatan arus sungai berkisar antara 0,8-1,07 m/ detik, sedangkan di bagian tengah sungai dapat mencapai lebih dari $2,0 \mathrm{~m} /$ detik. Arus yang kuat akan membawa zooplankton ke wilayah hilir dan terjadi penumpukan di wilayah tersebut. Dampak pasang 
surut terasa pengaruhnya di wilayah hilir sehingga zooplankton akan terbawa kembali ke arah hulu sungai. Faktor ini akan berpengaruh terhadap pertumbuhan zooplankton karena mempersulit kemampuan zooplankton dalam memperoleh makanan (Prianto et al., 2008).

\section{b. Keanekaragaman jenis}

Indeks keanekaragaman, zooplankton berkisar antara 0,8-1,5 (bulan Maret), antara 0,6-2 (bulan Juni), dan antara 0,4-1,5 (bulan Oktober) sedangkan hasil penelitian tahun 2004 berkisar antara 2,56-2,79 (Gambar 3). Hal ini mengindikasikan bahwa kondisi perairan pada tahun 2009 mengalami proses degradasi, dibandingkan tahun 2009. Rendahnya keanekaragaman zooplankton diduga karena pengaruh perubahan lingkungan akibat aktivitas manusia di sekitar Sungai Banyuasin seperti alih fungsi lahan yang menyebabkan meningkatnya kandungan total suspended solids dan total dissolved solid.

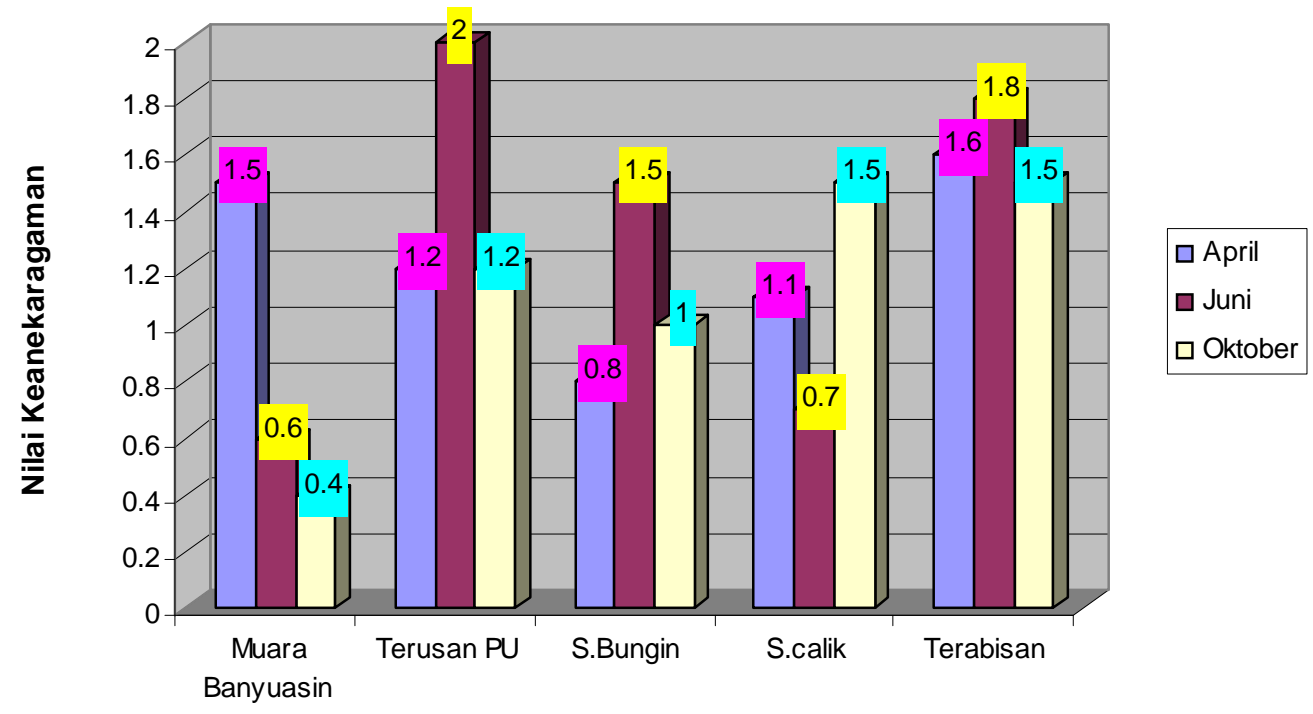

Stasiun Penelitian

Gambar 3. Keanekaragaman zooplankton menurut stasiun penelitian, tahun 2009.

Figure 3. Diversity of zooplankton by sampling station, 2009.

Menurut Siagian et al. (1996) jika nilai keanekaragaman $\left(\mathrm{H}^{\prime}\right)>3$ berarti sebaran atau keragaman individu tinggi yang menunjukan lingkungan tersebut belum mengalami gangguan (tekanan) atau struktur organisme yang ada berada dalam keadaan baik. Jika nilai H' antara 1-3 berarti sebaran atau keragaman individu sedang yang berarti lingkungan telah mengalami gangguan (tekanan) yang agak buruk. Sebaliknya jika $H^{\prime}<1$ berarti sebaran atau keragaman individu rendah yang berarti lingkungan tersebut telah mengalami gangguan (tekanan) atau struktur organisme yang ada berada dalam keadaan buruk.

Dengan mengacu pada nilai indeks di atas terlihat bahwa perairan ini cenderung tidak stabil karena rendahnya keanekaragaman. Tingginya keanekaragaman menunjukan suatu ekosistem yang seimbang dan memberikan peranan yang besar untuk menjaga keseimbangan terhadap kejadian yang merusak ekosistem dan spesies yang dominan dalam suatu komunitas memperlihatkan kekuatan spesies itu dibandingkan spesies lain (Clark,1974); Krebs, 1972; Arsil, 1999 dalam Dianthani, 2003).

\section{Indeks Mutu Lingkungan Perairan}

Selain membandingkan parameter fisika dan kimia perairan tahun 2009 dengan 2004 dan Peraturan Pemerintah No.82 Tahun 2001 Tanggal 14 Desember 2001, untuk menentukan kualitas perairan Sungai Banyuasin secara umum dapat digunakan juga metode penentuan indeks mutu lingkungan perairan. Rincian hasil perhitungan indeks mutu lingkungan perairan dapat dilihat pada Tabel 4. 
Tabel 4. Kriteria indeks mutu lingkungan perairan masing-masing stasiun penelitian di etuaria Sungai Banyuasin tahun 2009

Table 4. Water environment quality index criterion of each station in the estuary water of Banyuasin rivers in 2009

\begin{tabular}{ccccccrc}
\hline No. & $\begin{array}{c}\text { Lokasi/ } \\
\text { Location }\end{array}$ & April & $\begin{array}{c}\text { Keterangan/ } \\
\text { Remarks }\end{array}$ & Juni & $\begin{array}{c}\text { Keterangan/ } \\
\text { Remarks }\end{array}$ & Oktober & $\begin{array}{c}\text { Keterangan/ } \\
\text { Remarks }\end{array}$ \\
\hline 1. & Sungai Bungin & 40,14 & Buruk & 37,24 & Buruk & 49,54 & Buruk \\
2. & Muara Banyuasin & 42,25 & Buruk & 39,92 & Buruk & 47,6 & Buruk \\
3. & Terabisan & 55,77 & Sedang & 43,37 & Buruk & 35,63 & Buruk \\
4. & Sungai Calik & 43,99 & Buruk & 38,36 & Buruk & 36,45 & Buruk \\
5. & Terusan PU & 45,23 & Buruk & 45,16 & Buruk & 42,25 & Buruk \\
\hline
\end{tabular}

Keterangan/Remarks: 0-25: sangat buruk; 26-50: buruk; 51-70: sedang; 71-90: baik; 91-100: sangat baik

Apabila kualitas perairan Sungai Banyuasin dikaitkan dengan tingkat pencemaran, maka dapat dikatakan bahwa perairan di lokasi penelitian telah tercemar sedang sampai berat. Dari nilai indeks mutu lingkungan perairan pada Tabel 4, maka pada bulan April di Stasiun Terabisan yang memiliki nilai tertinggi $(55,77)$ yang berarti tercemar sedang.

\section{KESIMPULAN}

1. Estuari Sungai Banyuasin telah mengalami degradasi lingkungan. Beberapa parameter kualitas air seperti total suspended solids dan amoniak melebihi baku mutu lingkungan perairan yang diperbolehkan (Peraturan Pemerintah No.82 Tahun 2001).

2. Terjadinya degradasi lingkungan di estuari Sungai Banyuasin ditandai oleh rendahnya nilai kelimpahan dan keanekaragaman zooplankton pada tahun 2009 dibandingkan dengan tahun 2004.

3. Hasil penghitungan indek mutu lingkungan perairan diperoleh nilai $<50$ yang berarti Sungai Banyuasin mengalami tercemar berat.

\section{PERSANTUNAN}

Tulisan ini merupakan kontribusi dari kegiatan riset karakteristik habitat sumber daya perikanan di kawasan Pelabuhan Tanjung Api-Api, Sumatera Selatan, T. A. 2009, di Balai Riset Perikanan Perairan Umum-Mariana, Palembang.

\section{DAFTAR PUSTAKA}

American Public Health Association. 1980. Standard Methods for the Examination of Water and Waste Water. American Public Health Association Inc. New York. 120 pp.
Alaerts, G. \& S. S. Santika. 1984. Metode Penelitian Air. Penerbit Usaha Nasional. Surabaya.

Badan Pengendalian Dampak Lingkungan Daerah Pemerintah Provinsi Sumatera Selatan. 2004. Kegiatan Studi Analisis Mengenai Dampak Lingkungan Pembangunan Pelabuhan Tanjung Api-Api. Rekaprima Consultant. 138 pp.

Dianthani, D. 2003. Identifikasi jenis plankton di perairan Muara Badak, Kalimantan Timur. Makalah Falsafah Sains Program Pasca Sarjana. Institut Pertanian Bogor.

Downing, J. A. \& F. H. Rigler. 1984. A Manual on Methods for the Assesment of Secondary Productivity in Fresh Water. Black Well Scientific Publication. $51 \mathrm{pp}$.

Effendie, H. 2003. Telaah Kualitas Air bagi Pengelolaan Sumber Daya dan Lingkungan Perairan. Penerbit Kanisius. Yogyakarta. 245 pp.

Mizuno, T. 1979. Illustration of the Freshwater Plankton of Japan. Hoikusha Publishing Co. 352 pp.

Ott, W. R. 1978. Environmental Indices. Theory and Practice. Ann Arbor Science. Publ. Inc. Ann. Arbor Mich.

Paterson, M. 1998. Ecological Monitoring and Assessment Network (Eman) Protocols for Measuring Biodiversity: Zooplankton in Fresh Waters. Department of Fisheries and Oceans Freshwater Institute 501 University Crescent Winnipeg, Manitoba.

Prianto, E., Husnah, \& S. N. Aida. 2008. Inventarisasi jenis dan struktur ekologi zooplankton di Sungai Musi bagian hilir Sumatera Selatan. Jurnal 
Penelitian Perikanan Indonesia. Pusat Riset Perikanan Tangkap. Badan Riset Kelautan dan Perikanan Departemen Kelautan dan Perikanan. 14 (3): 263-271.

Raymond, J. E. E. 1963. Plankton and Productivity in the Ocean. Oxford. Pergamont Press.

Soedarsono, P., Subiyanto, W. Niniek, \& H. Sahala. 2002. Petunjuk Praktikum Planktonologi. Jurusan
Perikanan Fakultas Perikanan Universitas Diponegoro. Semarang.

Siagian, M., Hs, Saberina, \& H. Asmika. 1996. Penuntun Praktikum Ekologi Perairan. Fakultas Perikanan dan IImu Kelautan Universitas Riau. Pekanbaru. 109 pp. 